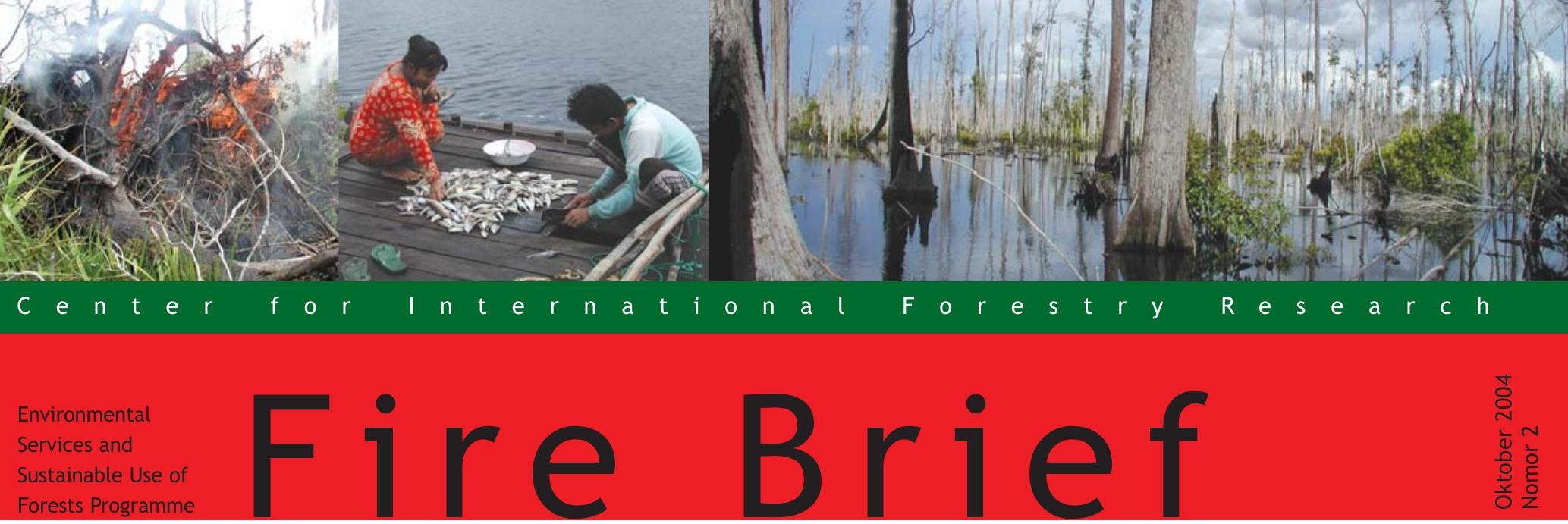

\title{
Kebakaran di lahan gambut Mahakam Tengah: Keselarasan antara mata pencaharian dan konservasi
}

Oleh: Unna Chokkalingam (u.chokkalingam@cgiar.org), CIFOR

Kebakaran besar yang berulang kembali secara drastis telah mempengaruhi lahan gambut Indonesia dalam beberapa dekade terakhir ini. Kebakaran di lahan gambut sangat berpengaruh terhadap lingkungan baik pada tingkat regional maupun global, termasuk emisi gas rumah kaca yang tinggi, kabut asap, hilangannya cadangan karbon dan keanekaragaman hayati. Kebakaran besar telah mempengaruhi lahan gambut di Mahakam Tengah, Kalimantan Timur selama musim kering tahun 1982/83 dan 1997/98, dan kebakaran kecil terjadi setiap tahun. Kebakaran tersebut terjadi karena kebiasaan pembakaran yang dilakukan oleh masyarakat untuk memenuhi kebutuhan hidupnya di lahan gambut.

\section{Lahan Gambut Mahakam Tengah}

Seluas 500.000 hektar wilayah lembah Mahakam Tengah terbentuk oleh lapisan tanah lempung sepanjang tepi Sungai Mahakam dan anak-anak sungainya yang besar, beberapa danau gambut dangkal, areal banjir musiman, dan hutan gambut yang luas. Kedalaman gambut rata-rata 8 meter dan ada yang lebih dari 15 meter di beberapa wilayah. Masyarakat yang hidup di wilayah ini berasal dari suku Kutai dan Banjar. Mereka menggunakan lahan gambut dan danau secara terbuka untuk kegiatan menangkap ikan dan reptil, mencari kayu dan mengumpulkan bahan bakar dan rumput. Kegiatan menangkap ikan merupakan sumber mata pencaharian utama. Perkampungan terletak di sepanjang sungai dan para pendatang memasuki lahan gambut melalui sungai, kanal, dan danau-danau. Tidak ada kegiatan pembalakan dalam skala komersial, konversi lahan ataupun pembangunan infrastruktur di dalam lahan gambut.

\section{Pola kebakaran dan sebab-sebabnya}

Kebakaran tahunan

Pada periode non El Niño, sekitar 24\% dari bentang alam mengalami kebakaran pada periode 1987-92 dan $17 \%$ pada periode 1992-97. Lebih kurang $81 \%$ dan $91 \%$ dari wilayah yang terbakar sudah terbakar sebelumnya. Hal ini menunjukkan bahwa peluang terjadinya kebakaran yang berulang-ulang di lahan gambut sangat besar. Kebakaran tahunan utamanya terjadi pada wilayah yang aksesibilitasnya tinggi

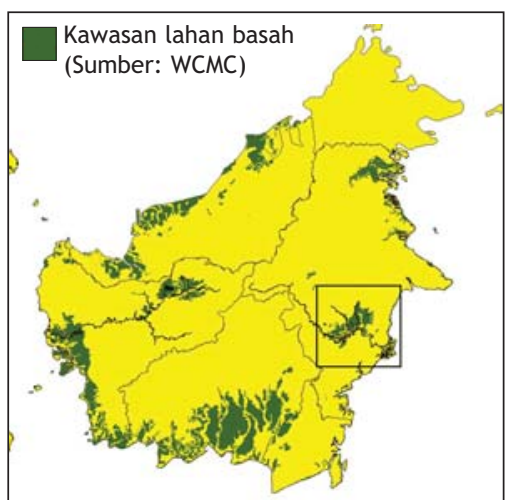

Lokasi lahan gambut Mahakam Tengah sepanjang Sungai Mahakam, Kalimantan Timur.

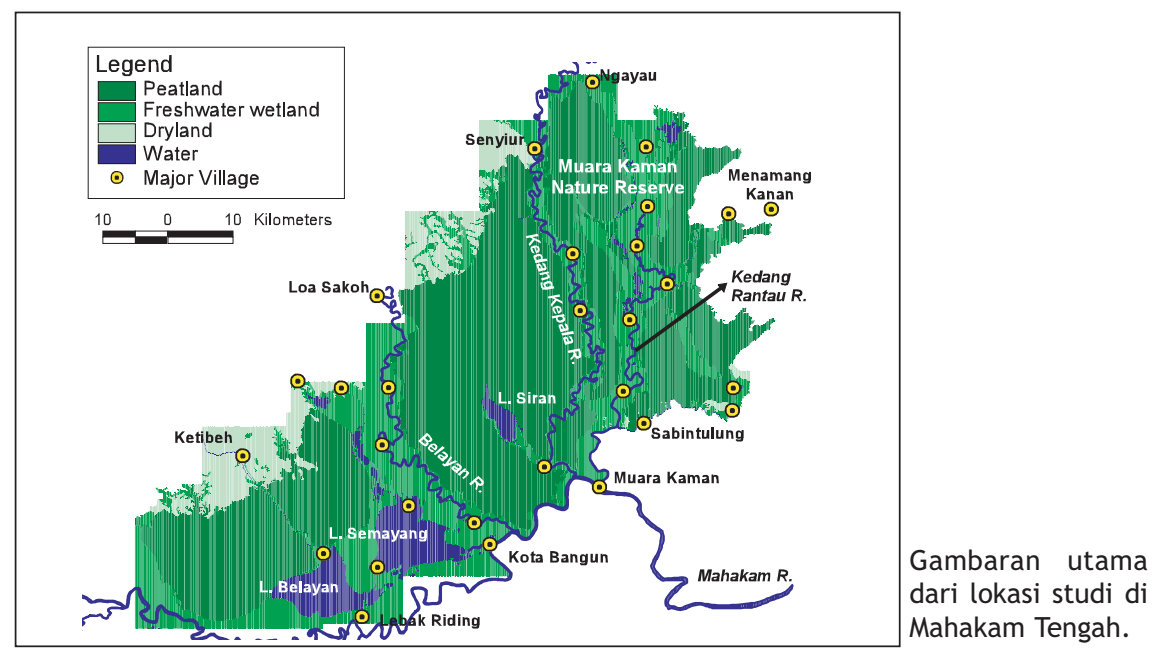


sepanjang sungai, danau dan kanal, serta areal pasang surut yang dapat dimasuki perahu kecil pada musim penghujan. Masyarakat lokal dan para pendatang menggunakan api untuk membersihkan tanaman dan mempermudah akses masuk ke lahan gambut untuk mencari ikan dan sumber-sumber pangan lainnya. Selain itu, juga untuk menambah habitat ikan dengan membuat dan memperluas areal tergenang dan kolam-kolam di areal hutan gambut yang terdegradasi.

Vegetasi yang terbakar setiap tahun disepanjang sungai. (Foto : Yayat Ruchiat)

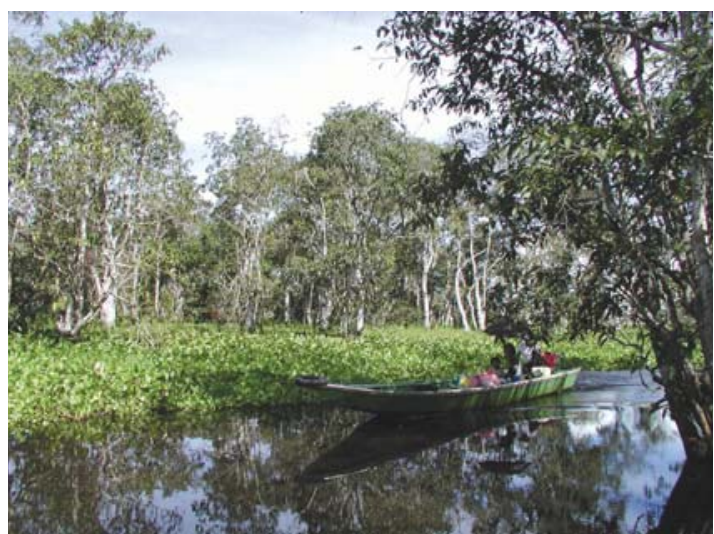

Genangan air yang berisi ikan di hutan gambut yang terbakar. (Foto : Andi Erman)
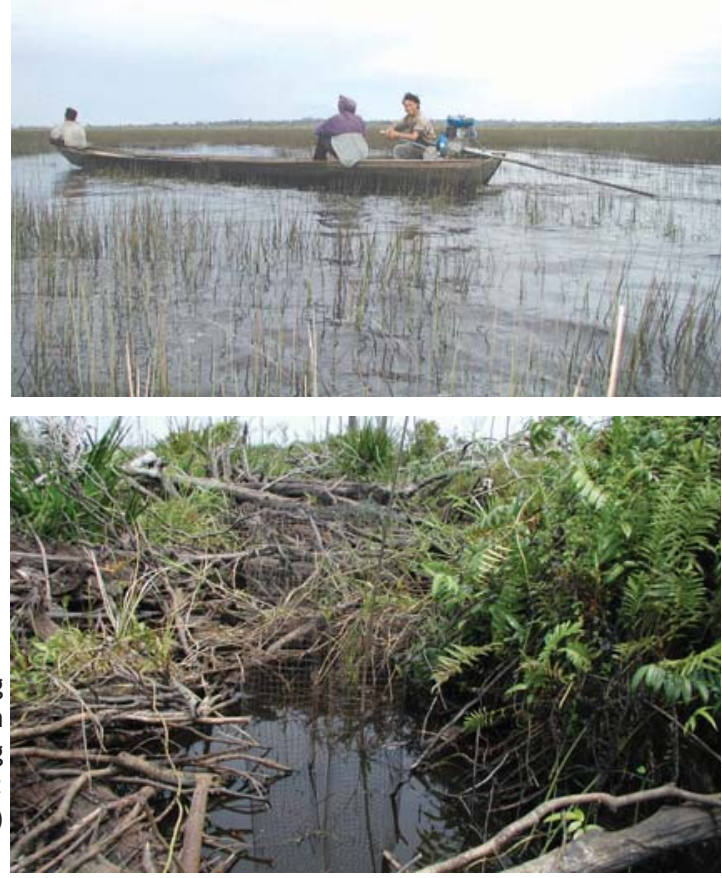

\section{Kebakaran El Niño 1982-83}

Lebih kurang 45\% kawasan yang diteliti mengalami kebakaran pada periode ini. Kebakaran tersebut terjadi dalam kawasan yang umumnya terbakar setiap tahun sepanjang tepi sungai dan menyebar ke areal yang berdekatan dengan hutan yang mengalami kekeringan. Kemungkinan api juga berasal dari kegiatan masyarakat di dalam hutan selama musin kering yang panjang.

\section{Kebakaran El Niño 1997-1998}

Pada periode ini, sekitar $72-85 \%$ dari lahan gambut di wilayah Mahakam Tengah terbakar. Sebagian besar atau sebesar 54\% merupakan areal hutan yang sebelumnya tidak pernah terbakar. Kebakaran besar ini disebabkan karena terjadinya kekeringan yang luar biasa serta pembakaran yang dilakukan oleh masyarakat di dalam perburuan kura-kura dan pengumpulan kayu lem. Masyarakat setempat mengalami kesulitan untuk menangkap ikan yang merupakan mata pencaharian utamanya. Hal ini disebabkan oleh air sungai yang mengering sehingga menyulitkan transportasi. Munculnya pasar yang baik untuk daging kura-kura dan kayu lem yang digunakan sebagai bahan pembuat obat nyamuk secara komersil, serta adanya ijin yang dikeluarkan pemerintah setempat untuk melakukan penangkapan kura-kura tanpa batas, pada awalnya merupakan jalan keluar untuk menanggulangi dampak krisis kekeringan ini. Ribuan masyarakat setempat kemudian mengalihkan mata pencahariannya pada kegiatan ini dan mereka memasuki areal hutan gambut di wilayah terpencil yang hampir tidak pernah didatangi sebelumnya. Teknik pembakaran digunakan untuk mempermudah akses ke dalam hutan, untuk berkemah, dan untuk mempermudah berburu kurakura. Dengan membakar vegetasi di sekelilingnya maka kura-kura akan terkonsentrasi pada areal yang basah. Kegiatan ini dilakukan masyarakat setempat selama musim kering yang panjang, dan terjadilah kebakaran yang meluas yang mengakibatkan rusaknya seluruh ekosistem gambut dan menimbulkan masalah asap.

\section{Dampak dan potensi pemulihannya}

Akibat terjadinya kebakaran pada tahun 1997-1998, kawasan hutan yang tadinya tertutup tajuk dengan cukup rapat (sebesar 63\%) menurun secara drastis menjadi tinggal 4\%; sedangkan hutan yang penutupan tajuknya sedang menurun dari $8 \%$ menjadi 5\%. Sedikitnya $83 \%$ bentang alam hutan sekarang ini berubah menjadi tipe vegetasi sekunder (hutan tajuk terbuka, vegetasi kerdil, dan padang rumput). Luasan vegetasi sekunder ini sangat jauh meningkat dibandingkan dengan luasan tahun 1987 yang hanya sekitar 33\%.

Setelah mengalami degradasi, lahan gambut akan sangat mudah terbakar. Kebakaran tahunan berulang kali terjadi pada lahan yang baru dibuka sejak tahun 1997-1998 dan mengubah sebagian hutan gambut menjadi tanah terbuka yaitu areal yang tergenang dan ditandai dengan hilangnya pohon penutup lahan dan gambut yang ada. Menurut responden lokal, adalah hal yang biasa terjadi pada lahan yang dibuka selama periode kekeringan yang panjang akan dibakar secara berulang dan mengalami transformasi untuk kegiatan penangkapan ikan. Lahan tergenang dan danau terbentuk karena kejadian-kejadian seperti itu. 


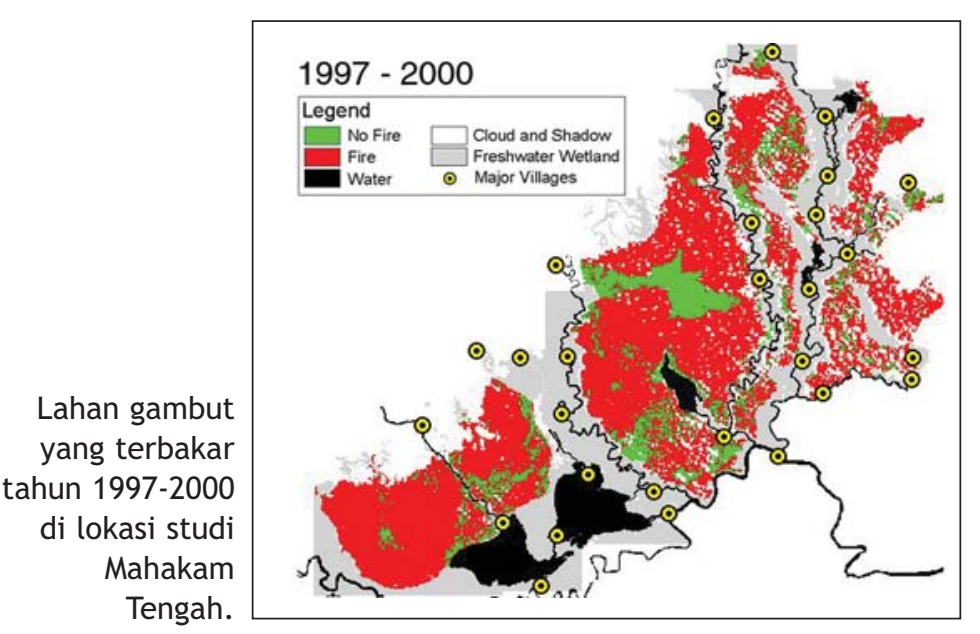

Hutan gambut dengan tingkat kebakaran yang rendah sampai moderat (sampai dengan 19\% pada lokasi penelitian) menunjukkan kemampuan yang baik untuk tumbuh kembali dengan cepat. Areal pedalaman yang terbakar hebat pada tahun 1997-98 dengan tingkat kebakaran yang berat (sampai 41\%) dapat juga pulih kembali jika dibiarkan tumbuh secara alami dan tidak ada gangguan lain. Masyarakat jarang sekali yang memasuki areal ini. Meskipun demikian, areal hutan pedalaman yang sudah pernah terbakar ini akan mudah terbakar kembali. Areal tersebut memiliki kandungan bahan bakar yang besar dari pohon yang mati dan serasah yang padat serta pertumbuhan liana, sementara tajuk yang terbuka mempercepat pengeringan. Kebakaran akibat kekeringan yang terjadi dengan cepat pada areal ini mungkin akan berakibat lebih fatal dan dampaknya akan berlangsung terus menerus.

\section{Faktor pendorong terjadinya pembakaran yang meluas oleh masyarakat setempat}

1. Pembakaran merupakan cara termurah yang digunakan oleh masyarakat setempat dalam memanfaatkan sumberdaya hutan di lahan gambut, sementara alternatif lain yang lebih efektif atau insentif bagi masyarakat untuk tidak melakukan pembakaran tersebut tidak tersedia.

2. Masyarakat lebih menghargai ikan daripada hutan gambut yang bernilai tinggi, dan oleh karenanya mereka tidak takut dan khawatir dengan degradasi hutan yang disebabkan oleh kebakaran yang berulang.

3. Perkembangan teknologi dan infrastruktur seperti jaring penangkap ikan (dari nylon), kanal kecil, kapal bermotor, dan jalan yang menghubungkan ke pasar telah turut berperan dalam meningkatkan kegiatan penangkapan ikan yang pada akhirnya meningkatkan kegiatan pembakaran.

4. Masyarakat yang memanfaatkan lahan gambut kurang memiliki perhatian akan dampak kebakaran terhadap hidrologi, kegiatan penangkapan ikan dan mata pencaharian masyarakat. Untuk mengetahui dampak jangka panjang terhadap hidrologi dan kegiatan penangkapan ikan dibutuhkan investigasi lebih lanjut secara terperinci.

\section{Faktor pendorong terjadinya kebakaran pada musim kering 1997/98}

1. Kondisi kekeringan luar biasa pada vegetasi dan gambut mempermudah api untuk membesar dan menyebar.

2. Kondisi air sungai yang mengering serta kesulitan transportasi membatasi kegiatan masyarakat setempat untuk mencari nafkahnya seperti menangkap ikan. Sementara, pilihan lain yang berkelanjutan untuk mendapatkan mata pencaharian sulit diperoleh.

3. Munculnya pasar baru yang bernilai tinggi untuk daging kura-kura dan kayu lem yang digunakan sebagai bahan pembuat obat nyamuk secara komersil.

4. Adanya ijin penangkapan kura-kura tanpa batas yang dikeluarkan pemerintah setempat untuk mengurangi krisis ekonomi yang terjadi akibat kekeringan tanpa memperhitungkan dampaknya terhadap lingkungan

\section{Kebutuhan masyarakat vs kepentingan regional/global}

Perlu diketahui cakupan apa saja yang harus dibahas dalam menyelesaikan masalah kebakaran lahan gambut dengan memahami keuntungan lokal dalam menggunakan teknik pembakaran dan kekhawatiran terhadap lingkungan secara regional sampai global atas semakin menyebarnya kebakaran. Kebijakan larangan pembakaran merupakan pilihan yang tidak dapat dijalankan karena kondisi alam dan akses yang sulit dilalui oleh masyarakat, banyaknya masyarakat yang melakukan kegiatan pembakaran lahan, dan pentingnya penggunaan api bagi masyarakat untuk memperoleh sumberdaya yang ada di lahan gambut. Untuk melindungi dan memanfaatkan lahan gambut Mahakam Tengah secara bijaksana, diperlukan harmonisasi antara nilai-nilai dan kebutuhan masyarakat lokal dengan perhatian komunitas di luar kawasan ini.

\section{Pendekatan untuk menyelaraskan mata pencaharian dan konservasi}

Upaya mencegah terjadinya pembakaran lahan gambut untuk kegiatan pengolahan tanah pada lapisan alluvial dan penangkapan ikan pada lahan gambut yang berdekatan dengan jalur air mungkin akan sulit dilakukan. Akan tetapi perluasan kebakaran tahunan dan degradasi hutan ke areal yang berdekatan yang diakibatkan oleh penggunaan 
api dalam penangkapan ikan dan api yang tidak terkontrol harus dihentikan. Banyak areal lahan gambut di pedalaman Mahakam Tengah dapat direhabilitasi atau dihutankan kembali apabila ada upaya pencegahan terjadinya pembakaran selama musim kering yang panjang. Dengan demikian diperlukan pencegahan masuknya ribuan orang ke dalam hutan untuk mencari kayu lem, kura-kura, atau sumberdaya lainnya selama musim kering dan masa krisis lainnya.

\section{Rekomendasi}

1. Menyusun program untuk mengatasi dampak $\mathrm{El}$ Niño di lahan gambut Mahakam Tengah yang bertujuan untuk mengurangi kegiatan pembakaran oleh masyarakat dan menyediakan alternatif kegiatan mata pencaharian lain yang berkelanjutan, khususnya pada saat-saat kritis. Kegiatan tersebut akan lebih baik apabila dilakukan di luar ekosistem lahan gambut yang mudah rusak. Meningkatkan kesadaran masyarakat setempat, membentuk lembaga kemasyarakatan lokal, dan membuat peraturan untuk mendukung serta menerapkan segala kebijakannya.

2. Mengkaji kelayakan teknis dan sosial ekonomi untuk kegiatan pengendalian kebakaran di wilayah tepi sungai dan daerah banjir yang mudah didatangi, terutama sekali pada musim kering yang panjang, sehingga laju kebakaran dapat ditahan.

3. Menjajaki kemungkinan penerapan pembayaran transfer dari komunitas masyarakat luar terhadap konservasi hutan gambut melalui inisiatif internasional seperti UNFCCC, CBD, Ramsar Convention, dan APMI. Manfaat yang diterima harus berimbang dan dapat dirasakan langsung oleh masyarakat lokal yang kehilangan manfaat ekonomi akibat perubahan pemanfaatan lahannya.

4. Melakukan penelitian apakah kebakaran yang berulang dan perubahan bentang alam akan berdampak negatif terhadap perikanan, kesehatan atau kualitas air. Jika ternyata benar, maka hal ini dapat digunakan untuk mengurangi minat masyarakat lokal untuk melakukan pembakaran dan melindungi hutan gambutnya di pedalaman.

5. Melarang pembangunan berskala besar (transmigrasi, hutan tanaman, pertanian, pembalakan komersial dan infrastruktur) yang mengakibatkan terjadinya deforestasi atau hilangnya lahan gambut, mempermudah akses menuju daerah pedalaman, dan akan meningkatkan tekanan akibat pertambahan penduduk.

\section{Referensi}

1. Chokkalingam, U., Kurniawan, I. and Ruchiat, Y. 2004. Manuscript. Fire, livelihoods and environmental degradation in the Middle Mahakam Peatlands. CIFOR, Bogor, Indonesia.

2. Chokkalingam, U., Kurniawan, I., Buitenzorgy, M., Anwar, S. and Hope, G. 2004. Manuscript. Impacts of recent fires on biodiversity in the Middle Mahakam Peatlands. CIFOR, Bogor, Indonesia.

3. Christensen, M. S., A. Mulu, and A. Akbar. 1986. Investigations into the fishery of the Middle Mahakam Area. German-Indonesian Technical Cooperation for Area Development, Samarinda, East Kalimantan, Indonesia.

4. Jepson, P., Momberg, F. and van Noord, H. 1998. Trade in reptiles from the Middle Mahakam Lake Area, East Kalimantan, Indonesia, with evidence of a causal link to the forest fires associated with the 1997/98 El Niño phenomena. Bio-Regional Management and Integrated Park Management Project Technical Memorandum 3. WWF Indonesia/ EPIQ/ USAID.
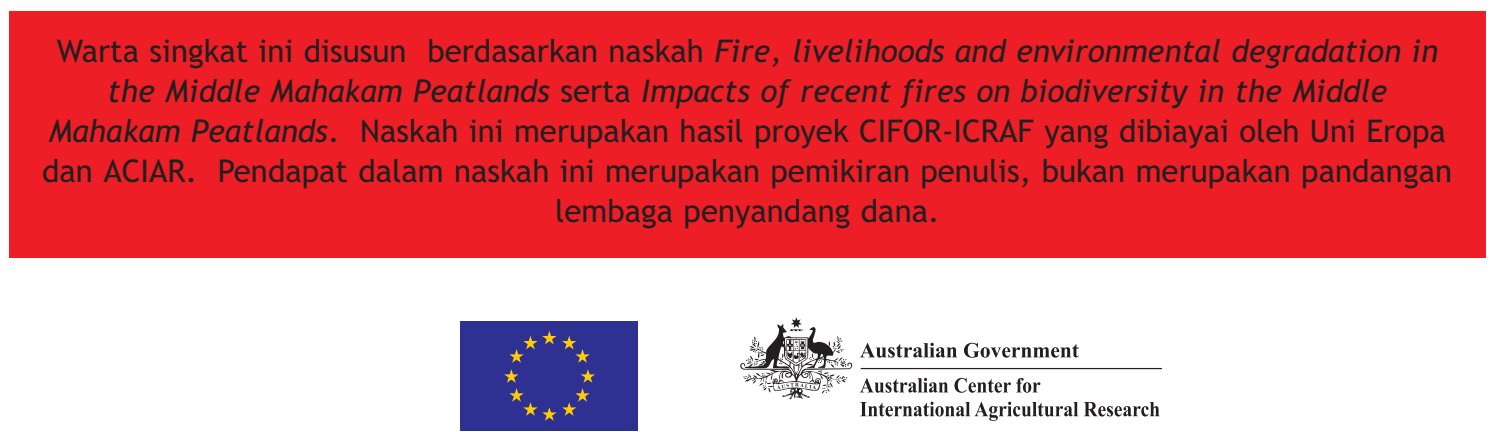

Australian Governmen

Australian Center for

International Agricultural Research
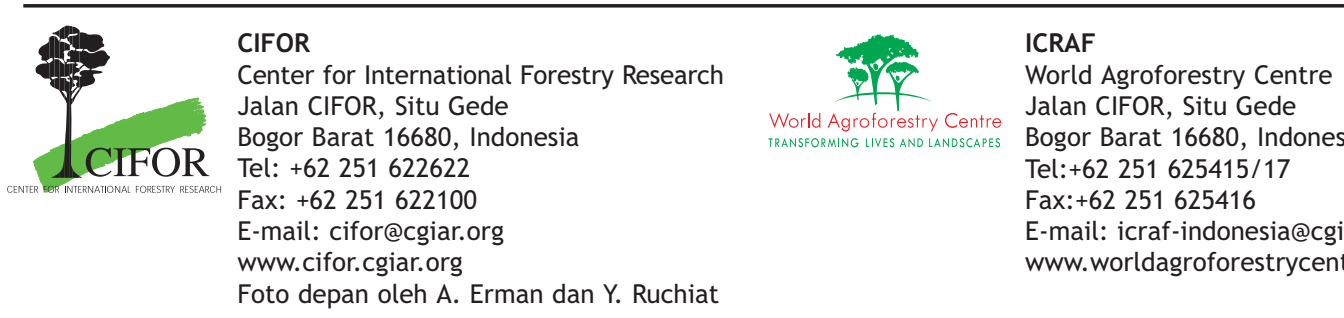

Jalan CIFOR, Situ Gede

Bogor Barat 16680, Indonesia

Tel:+62 251 625415/17

Fax:+62 251625416

E-mail: icraf-indonesia@cgiar.org

www.worldagroforestrycentre.org/sea

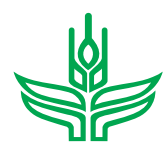

F U T U R E

HARY/EST

Warta ini juga tersedia dalam versi Bahasa Inggris 